\title{
Prevalent Parasitosis in Beef and Dairy Cattle Farms in Vidzeme Region
}

\author{
Dace Keidāne, Anna Krūklīte, Alīna Derbakova* \\ Latvia University of Agriculture, K. Helmaņa str. 4, Jelgava, LV-3004, Latvia
}

\begin{abstract}
The aim of the study was to investigate the beef and dairy cow parasitosis epizootic situation in Vidzeme region. Research was done throughout Vidzeme territory during the period of the years 2013-2014. The total number of animals examined was: 273 dairy and 90 young beef cattle aged from 6 months to two years and 248 dairy and 29 beef cows older than two years. For the diagnosis of helminthes standardized ovoscopic and larvoscopic methods were used. For the diagnosis of protozoa flotation and modified ZiehlNeelsen methods were used. The main species in the samples were Cryptosporidium spp., Eimeria spp. and Strongylus spp. In the young dairy and beef cattle aged from 6 months to two years and cattle older than two years Cryptosporidium spp. invasion accordingly was $32.6 \%$ and $19 \%$ (dairy cattle) and $62.2 \%$ and $65.5 \%$ (beef cattle); the invasion of Eimeria spp. 30\% and 7.3\% (dairy cattle) and 55.6\% and 10.3\% (beef cattle); and the invasion of Strongylus spp. was $17.6 \%$ and $13.7 \%$ (dairy cattle) and $43.3 \%$ and $27.6 \%$ (beef cattle). Both dairy and beef cattle were infected with Moniezia spp., Paramphistomum spp., Strongyloides spp. Dairy cows aged from 6 months to two years had Trichuris spp., Dictyocaulus spp. and Neoscaris spp. invasion.
\end{abstract}

Key words: cryptosporidium, eimeria, strongylus, parasitosis, cattle, Latvia.

\section{Introduction}

In Latvia, there have been no requirements for farmers to carry out any coprological examination of cattle in the last 20 years. Only few researches have been carried out in the last 5-10 years (Keidāne, Krūklīte, \& Medne, 2012; Lassen, 2011). Thereby, the situation regarding the most common cattle parasitosis in this country has still not been fully described.

In addition to climate change and the import of cattle, there is a great opportunity to introduce the parasite species which are not registered in the republic (Demiaszkiewicz, 2014).

Overall, worldwide cattle show a very high prevalence $(95.5 \%)$ of parasite infections. Out of this percentage, $75.1 \%$ had multiple parasites while $20.4 \%$ had a single parasite infection. Prevalence of Strongyles spp. (63.1\%) was the highest, followed by Fasciola spp. (51.1\%), Eimeria spp. (29.4\%), Paramphistomum spp. (25.9\%), Schistosoma spp. (21.7\%), Ascaris spp. (6.1\%) and then Moniezia spp. (2.3\%) (Squire, Amafu-Dey \& Beyuo,2013; Уркхарт , 2000). The prevention of parasitic diseases is based on the study of the epizootic situation and planning of preventive measures (Jasmer, Lahmers, \& Brown,2007; Heinrichs et al., 2003; Forbes et al., 2000; Уркхарт et.al., 2000).

The aim of this study was to find out prevalent parasitosis in dairy and beef cattle herds in Vidzeme region.

\section{Materials and Methods}

The research was done in Vidzeme region in the period from 2013-2014. The dairy and beef cattle were investigated. Animals were divided into the following four groups: dairy cattle aged from six months to two years $(n=273)$ and older than two years $(n=248)$; beef cattle aged from six months to two years $(n=90)$ and older than 2 years $(n=29)$. Samples were obtained from 62 cattle farms: 50 dairy cattle farms and 12 beef cattle farms. Laboratory tests were made in the laboratory of the department of Food and Environmental Hygiene, Faculty of Veterinary Medicine, Latvia University of Agriculture.

Rectal fecal samples collected into plastic bags were kept in a refrigerator at $4^{\circ} \mathrm{C}$ prior to examination. For the diagnosis of helminthes standardized ovoscopic and larvoscopic methods were used (Roepstorff \& Nansen, 1998). For the diagnosis of protozoa flotation and modified Ziehl-Neelsen methods (Henriksen \& Pohlenz, 1981) were used.

Parasitosis invasion extensive margin or prevalence (IE) was computed by dividing the number of infected animals by the total number of animals in a group. The correlation between the age of the animals and the validity of invasion was calculated using the t-test function in Microsoft Excel 2013 programme.

\footnotetext{
* Corresponding Author's email: alina.derbakova@gmail.com
} 


\section{Results and Discussion}

The present study showed that in Vidzeme parasitosis were found in both age groups of dairy (Figure 1) and beef cattle (Figure 2).

In both age groups of dairy cattle, the highest infestation extensive margin (IE )was showed by Cryptosporidium spp. IE $32.6 \%$ and $19 \%$ (p $<0.05)$, Eimeria spp. IE $30 \%$ and $7.3 \%(\mathrm{p}<0.01)$ and Strongylus spp. IE $17.6 \%$ and $13.7 \%(\mathrm{p}<0.05)$ correspondingly. The prevalence of Eimeria spp. and Strongylus spp. in both groups is quite similar to studies in other countries (Kounty et al., 2012; Knubben-Schweizer et al., 2010; Lassen \& Talvik, 2009; Forbes et al., 2000).

In group of young cattle from six months to two years in addition to the above mentioned invasions, we diagnosed Moniezia spp. IE 6.2\%, Neoscaris spp. (ascarids) IE 2.6\%, Trichuris spp. IE 1.5\%, Fasciola spp. IE $1.7 \%$, Paramphistomum spp. IE 1.7\%, Strongyloides spp. IE 1.1\% and Dictyocaulus spp. IE $1.7 \%$.

In cattle older than two years, we diagnosed Moniezia spp. IE 3\%, Trichuris spp. IE 0.4\%, Fasciola spp. IE $1.2 \%$, Paramphistomum spp. IE $0.8 \%$ and Dictyocaulus spp. IE $0.4 \%$.

Neoscaris vitulorum or calf ascarids was diagnosed in young cattle aged six months to two years IE $2.6 \%$. As we know, adult cattle do not suffer from ascarids (Davila, Irsic, \& Greiner, 2010; Zajac \& Conboy, 2006).

Dictyocaulus spp. invasion in cattle from six months to two years was IE $1.7 \%$, in cows older than two years IE $0.4 \%(\mathrm{p}>0.05)$. It is noted that the invasion of Dictyocaulusis spp. is more often diagnosed in young animals. (Elsheikla, 2011; Holzhauer et al., 2011; Hoglund, Ganheim, \& Alenius, 2003). The diagnosed invasion of Dictyocaulus spp. in the cattle older than two years could be explained by the import of cattle from different regions of the world.

Describing the invasion of Fasciola spp. IE 1.7\% and $1.2 \%$, Paramphistomum spp. IE $1.7 \%$ and $0.8 \%$, it can be concluded that the situation in Vidzeme region is similar to that of the previous studies about Latvia (Keidāne, Krūklīte, \& Medne, 2012), but comparing with the research conducted in other countries, the prevalence of parasites in Latvia is lower. Similarly, a study in Austria found that cattle Fasciola spp. IE was 16\% (Knubben-Schweizer et al., 2010). Regarding Paramphistomum spp., in Turkey the average IE throughout the year was $10.4 \%$ (Ozdal et al., 2010).

In beef cattle, like in dairy cattle, the highest IE both for young cattle from six months to two years and cattle older than two years has been observed in Cryptosporidium spp. IE $62.2 \%$ and $65.5 \%$ (p $<0.01$ ), Eimeria spp. $55.6 \%$ and $10.3 \%(\mathrm{p}<0.01)$ and Strongylus spp. IE $43.3 \%$ and $27.6 \%(\mathrm{p}<0.01)$ invasions (Figure 2). Completely different results were obtained from researchers in Alberta, Canada - the prevalence of Cryptosporidium spp. in beef cattle calves is 5\% (Ralston, McAllister, \& Olson, 2003; Gow \& Waldner, 2006). Compared with other countries, Eimeria spp. IE in Latvia is slightly higher: studies in Turkey found Eimeria spp. IE for calves in beef cattle herds 27.2\% (Cieek et al., 2007), 33.3\% in Hungary (Farkas, Szeidemann \& Majors,2007), $22.6 \%$ in Brazil (Almeda et al., 2011). Strongylus spp. IE in Latvia is lower than in other countries, for example, in Thailand IE is $100 \%$ (Lwin, 2011).

Along with the invasions mentioned above, young cattle were infected with Moniezia spp. IE $8.9 \%$ and Strongyloides spp. IE 1.1\%, whereas in cattle older than two years Paramphistomum spp. IE 3.4\% was diagnosed. In comparison with other countries, the invasion of these parasitosis in our country is

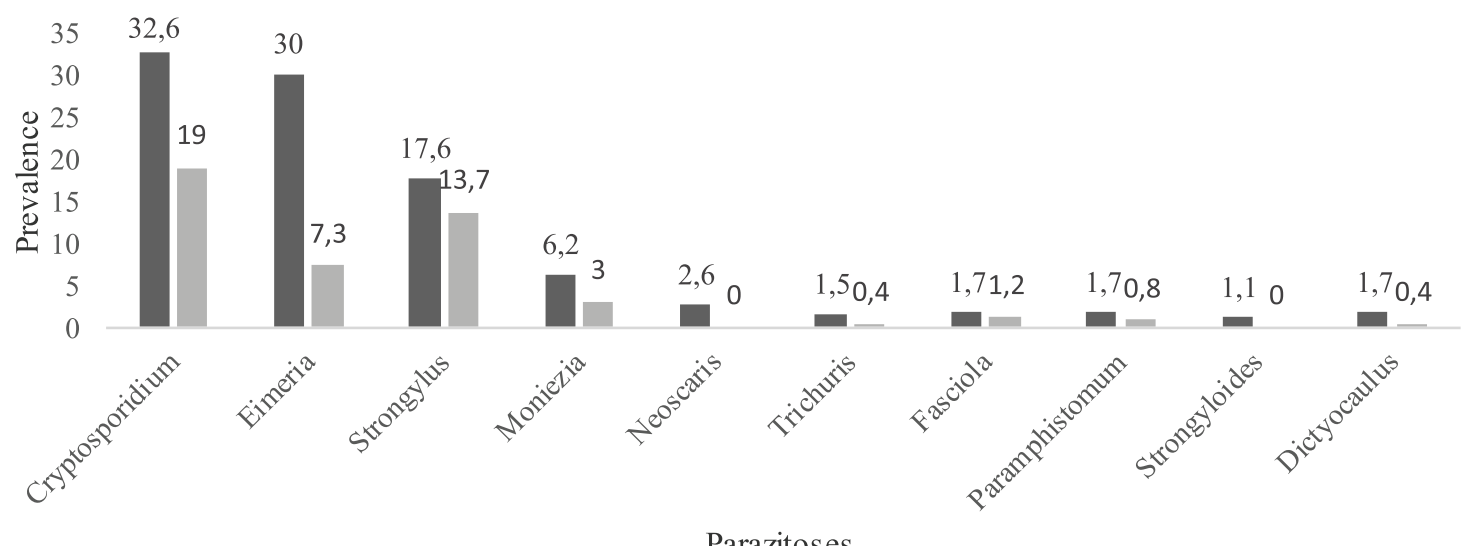

Parazitoses

Young cattle from 6 months to 2 years Cows older than 2 years

Figure 1. Prevalence (\%) of parasite invasion in dairy cattle. 


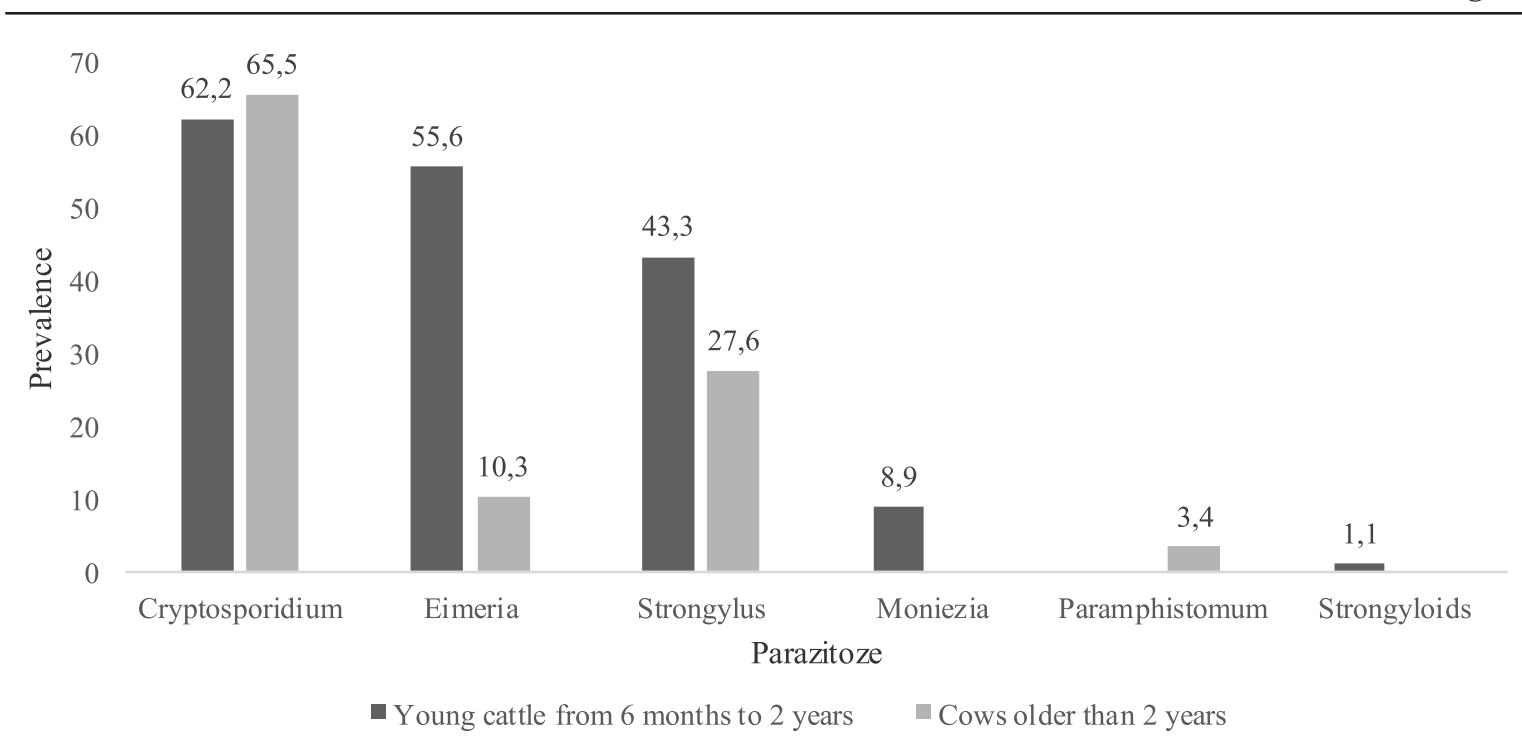

Figure 2. Prevalence (\%) of parasite invasion in beef cattle.

much lower. The research in Spain reported about Paramphistomum spp. IE was 29\% (GonzalesWarleta et al., 2013), in Thailand IE was $6.4 \%$ in beef cattle under 1 year old, and IE was $23.3 \%$ of cattle from one to two years old (Lwin, 2011). Similar IE has been mentioned regarding Moniezia spp.: in Thailand Moniezia spp. IE in cattle under one year was $12.9 \%$, from one to two years old it was $23.3 \%$ (Lwin, 2011). Relatively higher Strongyloides spp. IE was found in the Czech Republic - 4.3\% (Kvač \& Vitovec, 2007).

In general, younger animals are most likely to show signs of parasitism, while mature cows acquire a degree of immunity to parasites that reside in the gastrointestinal tract. Dairy cattle in a dry lot are less likely to have heavy worm infection than beef cattle on pastures (Gadberry \& Powell, 2011).

The results show that we should pay more attention to studies of cryptosporidiosis in Latvia because this disease has not been thoroughly investigated. Our research showed a high Cryptosporidium spp. invasion both in dairy and beef cattle herds. According to the sources of scientific literature, cryptosporidiosis is a serious invasion that is registered not only in the tropical zone countries (Kounty et al., 2012; Уркхарт et al., 2000), but also in Europe and it is shown by the recent research conducted in Latvia (Keidāne, Krūklīte, \& Medne, 2012; Lassen, 2011). We didn't include calves aged from the first to the tenth day of life in this study, which are in a highrisk group. Therefore, we will continue studies of the Cryptosporidium spp. invasion, treatment and prevention.

\section{Conclusions}

- In dairy cattle herds in the age group of six months to two years were diagnosed with low invasion of ascarides, Dictyocaulus spp. and Trichuris spp.

- Dairy cattle aged from six months to two years and cattle older than two years were more frequently infected with Cryptosporidium spp. IE $32.6 \%$ and $19 \%$, Eimeria spp. IE $30 \%$ and $7.3 \%$ and strongylatoses of digestive system IE $17.6 \%$ and $3.7 \%$.

- Beef cattle aged from six months to two years and cattle older than two years, were more frequently infected with Cryptosporidium spp. IE $62.2 \%$ and $65.5 \%$, Eimeria spp. IE $55.6 \%$ and $10.3 \%$ and Strongylus spp. $43.3 \%$ and $27.6 \%$.

- Both dairy and beef cattle herds were infected with Moniezia spp., Paramphistomum spp. and Strongyloides spp.

\section{References}

1. Almeda, V. D. A., Magalhaes, V. C. S., MunizNeta, E. S., Munhoz, A. D. (2011). Frequency of species of the genus Eimeria in naturally infected cattle in Southern Bahia, Northeat Brazil. Brazilian Journal of Veterinary Parasitology 20, 78-81 pp.

2. Cieek, H., Sevimli, F., Kozan, E., Kose, M., Eser, M., Dogan, N. (2007). Prevalence of coccidia in beef cattle in western Turkey. Parasitology Research. 101: 1239- 1243 pp.

3. Davila, G., Irsic, M., Greiner, E.C. (2010). Toxocara vitulorum in beef calves in North Central Florida. Veterinary Parasitology 168, 261-263 pp. 
4. Demiaszkiewicz, A. W. (2014). Migration and the introduction of wild ruminants as a cause of parasite exchange and emergence of new parasites. Annals of Parasitology 60 (1), 25-30 pp.

5. Elsheikla, H. (2011). Employing integrated approach to lungworm control in cattle. Veterinary Times No 04, 16 p.

6. Farkas, R., Szeidemann, Z., Majors, G. (2007). Studies on coccidiosis of calves in Hungarian dairy farms. Parasitology Research 101, 113 120 pp.

7. Forbes, A. B., Huckle, C. A., Gibb, M. J., Rook, A. J., Nuthall, R. (2000). Evaluation of the effects of nematode parasitism on grazing behavior, herbage intake and growth in young grazing cattle. Veterinary parasitology. Netherland. Jun 10; 90 (1-2): 111-118 pp.

8. Gadberry, S., Powell, J. (2011). Internal parasites in beef and dairy cattle. Retrieved 23 October, 2015, from https://www.extension.org: 443/ pages/11022/internal-parasites-in-beef-anddairy-cattle.

9. Gonzalez-Warleta, M., Lladosa, S., CastroHermida, J. A., Martinez-Ibeas, A. M., Conesa, D., Munoz, F., Lopez-Quilez, A., MangaGonzales, Y., Mezo, M. (2013). Bovine paramphistomosis in Galicia (Spain): prevalence, intensity, etiology and geospatial distribution of the infection. Thesis. 32, 11-14 pp.

10. Gow, S., Waldner, C. (2006). An examination of the prevalence of and risk factors for shedding of Cryptosporidium spp. and Giardia spp. in cows and calves from western Canadian cow-calf farms. Veterinary parasitology 137, 50-61 pp.

11. Heinrichs, A. J., Holden, L., Ishler, V., Jones, C. M., Muller, L., Varga, G., Wu, Z. (2003). Penn Statee, Dairy and Animal Science, cattle nutrition, cited 6/17/03. Retrieved 15 September, 2015, from das.psu.edu/dairyutrition/// dairynutrition/calves/rumen/index.cfm.

12. Henriksen, S. A., Pohlenz, J. F. L. (1981). Staining of cryptosporidia by a modified ZiehlNeelsen. Acta Veterinaria Scandinavica 22:594$596 \mathrm{pp}$.

13. Hoglund, I., Ganheim, C., Alenius, S. (2003). The effect of treatment with eprinomectin on lungwarm at casly potency on the development of immunity in young cattle. Veterinary Parasitology 114:205-214 pp.

14. Holzhauer, M., van Schaik, G., Saatkamp, H. W., Ploeger, H. W. (2011). Lungworm outbreaks in adult dairy cows: estimating economic losses and lessons to be learned. Vet Rec. Nov 5, 169(19); 494 p.
15. Jasmer, D. P., Lahmers, K. K., Brown, W. C. (2007) Parasite Immunology. Department of Veterinary microbiology and pathology, USA; 29(3): 139-151 pp.

16. Keidāne, D., Krūklīte, A., Medne, R. (2012). Prevalent parasitosis of cows in Latvia. International Scientific Conference Animals. Health. Food Quality Proceedings of Conference on "Current events in veterinary research and practice” 22nd - 23rd November 2012, Jelgava, Latvia; 68-71 pp.

17. Knubben-Schweizer et al. (2010). Efficiency of control of bovine fasciolosis. Proceeding of the XXVI World Buiatrics Congress. Santago, Chile, Nov 14-18. Reprinted in IVIS with the permission of the Congress organizers, 25-27 pp.

18. Koutny, H., Joachim, A., Tichy, A., Baumgartner, W. (2012). Bovine Eimeria species in Austria. Parasitol Res. May; 110(5): 1893-901 pp.

19. Kvač, M., Vitovec, J. (2007). Occurrence of Strongyloides papillosus associated with extensive pulmonary lesions and sudden deaths in calves on a beef farm in a highland area of South Bohemia (Czech Republic). Helmintologia, 44, 1:10-13 pp.

20. Lassen, B. (2011). The prevalence of Eimeria and Cryptosporidium in large Latvian cattle herds. Veterinaria ir zootechnika, T54 (76). 47$52 \mathrm{pp}$.

21. Lassen, B., Talvik, H.(2009). Parasitic protozoans in lifestock and pets in Estonia. Rewiew. Veretinarija ir zootechnika (Vet Med Zoot). ISSN 1392-2130; 46 (68): 30-36 pp.

22. Lwin, K. S. (2011). Prevalence of Cryptosporidium, Giardia and other internal parasites in dairy and beef cattle of Mae on District, Chiang Mai Thailand. Thesis, Chiang Mai University and Freie Universität Berlin, Chiang Mai, Thailand, 65-77 pp.

23. Ozdal, N., Gul, A., Ilhan, F., Deger, S. (2010). Prevalence of Paramphistomum infections in cattle and sheep in Van Province, Turkey. Helmintologia, 47, 1:20-24 pp.

24. Ralston, B. J., McAllister, T. A., Olson, M. E. (2003). Prevalence and infection pattern of naturally acquired giardiasis and cryptosporidiosis in range beef calves and their dams. Veterinary Parasitology. 114, 113122 pp.

25. Roepstorff, A., Nansen, P. (1998). Epidemiology, diagnosis and control of helminth parasites of swine. FAO Animal Health Manual. Rome, 51$56 \mathrm{pp}$.

26. Squire, S. A., Amafu-Dey, H., Beyuo, J. (2013). Epidemiology of gastrointestinal parasites of 
cattle from selected locations in Southern Ghana. Livestock Research for Rural Development 25 (7). 14-18 pp.

27. Zajac, A. M., Conboy, G. A. (2006). Veterinary Clinical parasitology. Blackwell Publishing Ausen, IA 82 p.
28. Уркхарт Г. и др. (2000). Ветеринарная паразитология (Veterinary parasitology) Москва: Аквариум,17-26 стр. (in Russian). 